AperTO - Archivio Istituzionale Open Access dell'Università di Torino

\title{
Cyclodextrin-Grafted Silica-Supported Pd Nanoparticles: An Efficient and Versatile Catalyst for Ligand-Free C-C Coupling and Hydrogenation
}

\section{This is the author's manuscript}

Original Citation:

Availability:

This version is available http://hdl.handle.net/2318/1624618

since 2017-02-13T15:39:52Z

Published version:

DOI:10.1002/cctc.201501225

Terms of use:

Open Access

Anyone can freely access the full text of works made available as "Open Access". Works made available under a Creative Commons license can be used according to the terms and conditions of said license. Use of all other works requires consent of the right holder (author or publisher) if not exempted from copyright protection by the applicable law. 
This is the author's final version of the contribution published as:

Martina, Katia; Baricco, Francesca; Caporaso, Marina; Berlier, Gloria; Cravotto, Giancarlo. Cyclodextrin-Grafted Silica-Supported Pd Nanoparticles: An Efficient and Versatile Catalyst for Ligand-Free C-C Coupling and Hydrogenation. CHEMCATCHEM. 8 (6) pp: 1176-1184. DOI: $10.1002 /$ cctc. 201501225

The publisher's version is available at: http://doi.wiley.com/10.1002/cctc.201501225

When citing, please refer to the published version.

Link to this full text:

http://hdl.handle.net/2318/1624618 


\title{
Cyclodextrin-grafted silica supported Pd nanoparticles: an efficient and versatile catalyst for ligand free $\mathrm{C}-\mathrm{C}$ coupling and hydrogenation
}

\author{
Katia Martina, ${ }^{[a]}$ Francesca Baricco, ${ }^{[a]}$ Marina Caporaso, ${ }^{[a]}$ Gloria Berlier ${ }^{[b]}$ and Giancarlo Cravotto*[a]
}

\begin{abstract}
Silica is an extremely versatile support which is capable of hosting metal NPs and enhancing their stability and reactivity. In this study, a novel Pd supported cyclodextrin/silica support, which we have denoted PdNPs/Si-CD, has been prepared. The highly efficient and homogeneous impregnation of small palladium nanoparticles in this support has been carried out under conventional conditions, while ultrasound irradiation has a beneficial effect on catalyst preparation. The catalyst has exhibited excellent activity in ligand free C-C Suzuki end Heck couplings over a large number of aryl iodide and bromides, while MW irradiation use cuts down reaction time. PdNPs/Si-CD have shown high activity and selectivity in the hydrogenation reaction, while the semihydrogenation of phenylacetylene was studied with excellent results.
\end{abstract}

\section{Introduction}

The discovery, in the late 1980's by Haruta et al., that $\alpha-\mathrm{Fe}_{2} \mathrm{O}_{3}$ supported Au nanoparticles of smaller than $5 \mathrm{~nm}$ are very active in $\mathrm{CO}$ oxidations caused the catalysis community to realize the significance that size has on catalytic properties..$^{1,2}$ The high surface energy of these particles makes them extremely reactive meaning that most systems undergo aggregation without protection or surface passivation. ${ }^{3}$ Whereas it is well known that nanosize in catalysis is important because of high surface areas and reactivities, the mechanistic insight of a nanocatalyst is not so obvious. Several other key catalyst parameters need to be considered. These include nanoparticle shape and any synergic effects that may exist between metal and support. ${ }^{4}$ Nanoparticles (NPs) have been so far been synthesized using various chemical and physical methods. ${ }^{5}$ The preparation of NPs frequently involves the reduction of metal ions in solutions or in high temperature gaseous environments meaning that not only has the search for new nanocatalysts been a focus of interest but even

[a] Dr. K. Martina, F. Baricco, M. Caporaso, Prof. G. Cravotto Dipartimento di Scienza e Tecnologia del Farmaco and NIS - Centre for Nanostructured Interfaces and Surfaces

University of Turin

via Pietro Giuria 9, 10125 Turin (Italy)

Fax: (+ 39) 0116707687

E-mail: giancarlo.cravotto@unito.it

[b] Dr. G. Berlier

Department of Chemistry and NIS - Centre for Nanostructured

Interfaces and Surfaces

University of Turin

Via P. Giuria 7, 10125 Turin, (Italy) the optimization of metallic NP green syntheses has attracted significant attention from the scientific community. ${ }^{6}$ Palladium catalysts have emerged as powerful and versatile tools in organic synthesis ${ }^{7}$. A number of palladium catalysts are commercially available and, interestingly, their reactivity, stability and selectivity can be tuned by ligands ${ }^{8}$ (phosphines, carbenes, amines, etc.) and/or additives ${ }^{9}$. Although ligand containing molecular palladium catalysts, have long proven to be efficient and very popular, ${ }^{10}$ continuous investigation into "green", so-called "ligandless", palladium catalysts is ongoing. ${ }^{11}$ Phosphine free C$\mathrm{C}$ coupling reactions may involve the presence of nanosized $\mathrm{Pd}$ colloids as suggested by Reetz et al.. In fact, Bonneman et al. ${ }^{12}$ observed in 1991 that they are generated from $\mathrm{Pd}(\mathrm{II})$ salts in polar solvents in the presence of tetraalkylammonium salts at high temperatures. ${ }^{13}$ PdNPs have now become a valuable alternative and provide several "green" chemistry benefits. ${ }^{14}$ One of the principle advantages that these systems present is the fact that they are catalytically active in low amounts driving interest from industry in this field. Recent years have thus seen various syntheses being scaled up to the kilogram scale. ${ }^{15}$ De Vries, ${ }^{16}$ has detailed PdNPs' role as a source of Pd atoms that detach from the surface during oxidative addition and undergo highly efficient turnover in solution. At high temperature, PdNPs are stabilized by the presence of polar solvents or ammonium salts and ionic liquids that influence PdNP dimensions and favour productive reactions ${ }^{17}$. Heterogeneous supports also provide a valuable influence on reaction outcome. Many studies have validated the use of $\mathrm{Pd}$ colloids in Heck reactions, although reactions with less reactive aryl bromides have not been very successful in the absence of stabilizers, such as ammonium salts, or ligands.

Silica is an extremely versatile support and one which is capable of hosting metal NPs, enhancing their stability and reactivity ${ }^{18}$. Silica has found widespread use in the preparation of solid supported PdNPs because of the benefits that it provides, which include excellent stability (chemical and thermal), mechanical robustness, good accessibility and porosity. In fact, a number of organic-inorganic hybrid materials have seen extensive use in the design of novel catalytic systems. ${ }^{19}$ Our recent study into the efficient grafting of cyclodextrin (CD) into an inorganic silica framework provided a material which showed a hydrophilic/ hydrophobic profile and surface reactivity which were modified with respect to material bulk properties. ${ }^{20}$ To the best of our knowledge, only one manuscript has so far reported the use of a CD-silica derivative in the preparation of a heterogeneous PdNP catalyst and its subsequent Heck reaction. ${ }^{21}$ This work therefore aims to exploit our experience in CD synthesis to explore this field further. ${ }^{22}$ 
We herein report the preparation of a new PdNP catalyst which attempts to amalgamate the properties of an amino alcoholic branched spacer and a triazolyl- $\beta-C D$ derivative to effectively immobilize and stabilize PdNPs. Our intention here is to produce an extremely versatile catalyst and explore its potential over a series of hydrogenations and coupling reactions, such as Suzuki, Heck and Sonogashira, which are ranked among the most general transformations in organic synthesis.

Scientists have recently devoted a great deal of research to designing more environmentally sound and low impact protocols to operate under non conventional conditions. ${ }^{23}$ Solvent-free and aqueous media reactions, NPs, microwave assisted and ultrasound promoted syntheses are all key developments in the design of greener protocols. Sonochemistry has been very reliably employed in the synthesis of small, high production yield NPs, while the selective heating of catalytically active metal species under microwave irradiation is currently generating significant interest. ${ }^{24}$ The objective of this manuscript is to investigate the efficacy of ultrasound irradiation in the preparation of $\mathrm{Pd} / \mathrm{Si}-\mathrm{CD}$ hybrid system supported PdNPs. Non-conventional MW irradiation has also been used to optimize the synthetic procedure for high reaction yields in short reaction times. All protocols were designed to operate without a stabilizer (ammonium salts or ionic liquid) and be ligand and free so as to fulfil green chemistry criteria.

\section{Results and Discussion}

The silica derivative consists of $\beta-C D$ anchored to silica via an alkyl hydroxyl amino spacer (Scheme 1). The Silica was derivatized with 3-glycidoxypropyltrimethoxysilane (GPMS) that was then reacted with 10-undecynil-1-amine (Und) to open the epoxide ring. The Si-CD derivative was finally obtained from a Cucatalyzed azide-alkyne cycloaddition (CUAAC) with 6-monoazido6 -deoxy- $\beta$-CD. The synthetic protocol can be performed either under MW irradiation or via mechanochemical activation as already described in a previous study. ${ }^{20}$ All samples were extensively characterized by TGA, elemental analysis, IR, BET and HRTEM. A highest final loading of $135 \mu \mathrm{mol} / \mathrm{g}$ of $\beta$-CD was measured when all three steps were performed under MW irradiation. ${ }^{20}$

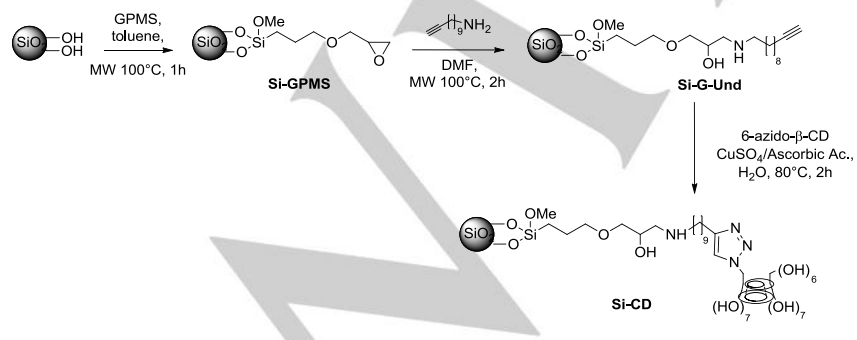

PdNPs were immobilized on the Si-CD via the reduction of the $\mathrm{Pd}(\mathrm{OAc})_{2}$ precursor in ethanol or in water. The procedure was repeated at room temperature and at reflux. The reaction was monitored via the colour change in the silica support.

The reaction from Si-G-Und afforded a light grey silica derivative, while all the other attempts with Si-CD furnished a dark grey solid. ICP analyses confirmed that Pd content was lower, 2.3 Pd (\%wt), when $C D$ was absent from the silica support (See Table 1, entry 1-4). Pd content in the Si-CD samples was in the 4.7 to $6 \%$ range and the highest amount was achieved when the loading was performed in ethanol at reflux. Ultrasound irradiation of the $\mathrm{Pd}(\mathrm{OAc})_{2}$ solution in ethanol with Si-CD afforded $4.7 \% \mathrm{Pd}$.

Table 1. Preparation conditions and $\mathrm{Pd} w \mathrm{wt} \%$ content of the various supported Pd catalysts.

\begin{tabular}{|c|c|c|c|c|}
\hline $\begin{array}{l}\text { Entry } \\
\text { (sample name) }\end{array}$ & $\begin{array}{l}\text { Starting } \\
\text { Silica } \\
\text { deriv. }\end{array}$ & $\begin{array}{l}\text { Reaction } \\
\text { condition }^{[a]}\end{array}$ & $\begin{array}{l}\mathrm{Pd} \text { content }{ }^{[\mathrm{b}]} \\
\text { wt\% }\end{array}$ & $\begin{array}{l}\text { Particle } \\
\text { size } \\
(\mathrm{nm})\end{array}$ \\
\hline $\begin{array}{l}1 \\
\text { (Pd/Si-Und) }\end{array}$ & $\begin{array}{l}\text { Si-G- } \\
\text { Und }\end{array}$ & $\begin{array}{l}\text { EtOH, } \\
\text { Reflux, 2h }\end{array}$ & 2.3 & n.d. \\
\hline $\begin{array}{l}2 \\
(\mathrm{Pd} / \mathrm{Si}-\mathrm{CD}(\mathrm{A}))\end{array}$ & Si-CD & $\begin{array}{l}\text { EtOH, r.t., } \\
48 \mathrm{~h}\end{array}$ & $4.75 \%$ & 14.7 \\
\hline $\begin{array}{l}3 . \\
(\mathrm{Pd} / \mathrm{Si}-\mathrm{CD}(\mathrm{B}))\end{array}$ & Si-CD & $\begin{array}{l}\mathrm{EtOH}, \\
\text { reflux } 2 \mathrm{~h}\end{array}$ & $6.0 \%(5.95)^{[d]}$ & $\begin{array}{l}5.4 \\
(6.2)^{[e]}\end{array}$ \\
\hline $\begin{array}{l}4 . \\
(\mathrm{Pd} / \mathrm{Si}-\mathrm{CD}(\mathrm{C}))\end{array}$ & Si-CD & $\begin{array}{l}\mathrm{H}_{2} \mathrm{O}, 80^{\circ} \mathrm{C} \\
2 \mathrm{~h}\end{array}$ & 4.88 & 14.1 \\
\hline $\begin{array}{l}5 . \\
(\mathrm{Pd} / \mathrm{Si}-\mathrm{CD}(\mathrm{US}))\end{array}$ & Si-CD & $\begin{array}{l}\mathrm{EtOH}, \mathrm{US}, \\
2 \mathrm{~h}\end{array}$ & $4.7 \%$ & $4.0^{[\mathrm{e}]}$ \\
\hline
\end{tabular}

[a] All reactions were performed in the presence of $\mathrm{Pd}(\mathrm{OAc})_{2} 400 \mu \mathrm{mol} / \mathrm{g}$; [b] Determined by inductively coupled plasma analysis (ICP); [c] Average particle size of Pd particles was measured on the basis of TEM images; [d] data measured on the catalyst after a first usage; [e] the particle size was measured by XRD.

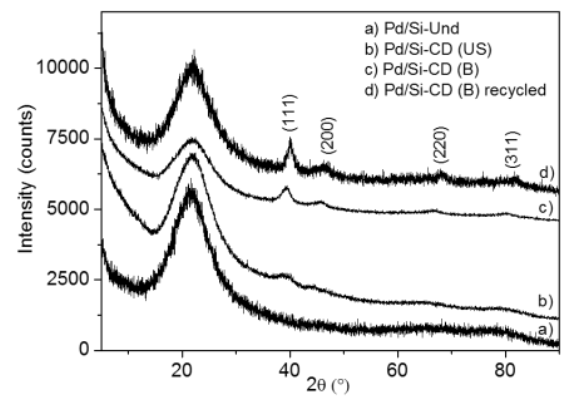

Figure $1 \mathrm{XRD}$ patterns measured on samples listed in Table 1: a) $\mathrm{Pd} / \mathrm{Si}$-Und; b) $\mathrm{Pd} / \mathrm{Si}-\mathrm{CD}(\mathrm{US})$; c) Pd/Si-CD (B) and d) recycled Pd/Si-CD (B). 


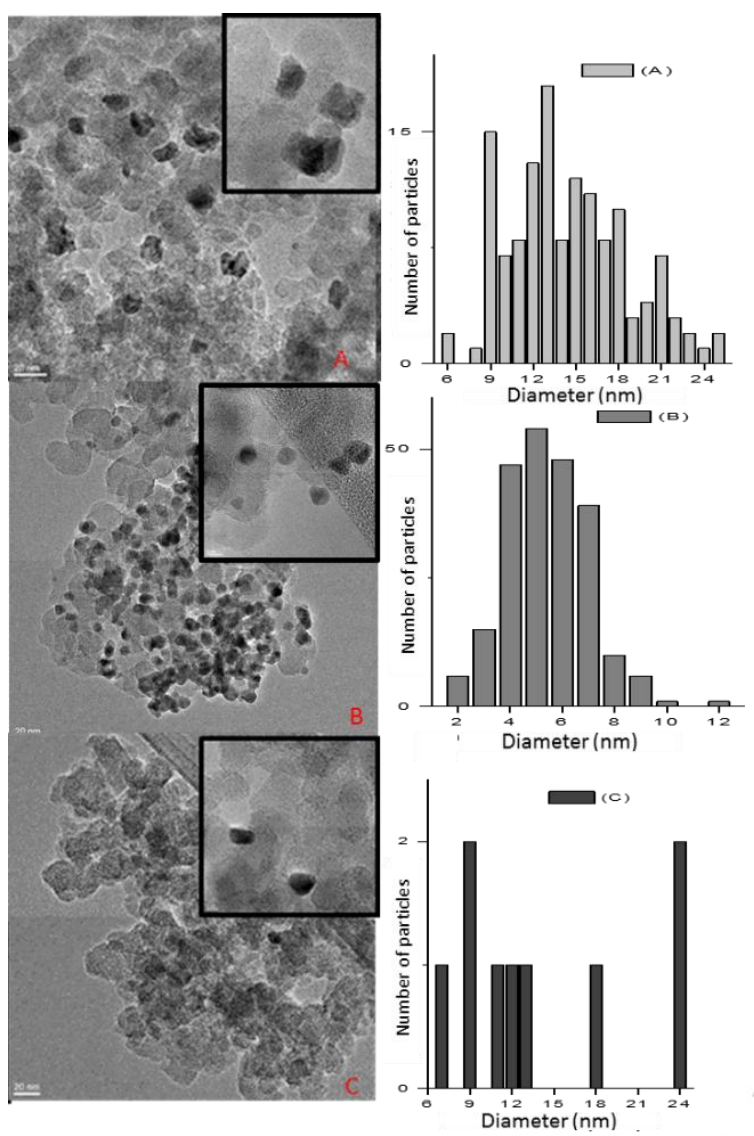

Figure 2. TEM images of $P d / S i C D$ catalyst $A) P d / S i-C D(A)$ : sample was prepared in $\mathrm{EtOH}$ at r.t. Table 1 Entry 2; $\mathrm{B}) \mathrm{Pd} / \mathrm{Si}-\mathrm{CD}(\mathrm{B})$ : sample was prepared in $\mathrm{EtOH}$ at reflux (Table 1, Entry 3) C) Pd/Si-CD (C): sample was prepared in water at $80^{\circ} \mathrm{C}$ entry 4 Table 1 . Pd particle size distributions measured on the same samples are also reported.

The catalysts' XRD patterns show that PdNPs exist on the $\mathrm{Pd} / \mathrm{Si}$ CD substrates (Figure 1, curves $c$ ). The strongest peak in the XRD pattern $\left(21.86^{\circ}\right)$ is the typical diffused scattering of the amorphous $\mathrm{SiO}_{2}$ support. The other weaker and broader peaks are indexed as the (111), (200), (220), and (311) planes of the PdNPs (cubic phase, JCPDS 46-1043). A slight shift in $2 \theta$ values is observed, with respect to standard references, in all peaks, which suggests that a small increase in crystallite d-spacing occurs as a consequence of particle nanosize. These peaks are absent in the sample that was prepared without CD (sample $\mathrm{Pd} / \mathrm{Si}$-Und, curve a). Average crystallite size, estimated using the Scherrer formula, is $6.2 \mathrm{~nm}$ for sample $B$ and $4.0 \mathrm{~nm}$ for sample prepared in the ultrasound bath.

TEM images of the catalyst are shown in Figure 2. $\mathrm{Pd} / \mathrm{Si}-\mathrm{CD}$ samples $A$ and $C$, which were prepared in ethanol at r.t. and water at $80^{\circ} \mathrm{C}$ respectively, consist of non-uniform (mainly spheroidal) particles with a diameter range of 6 to $25 \mathrm{~mm}$ (Figure 1, examples $\mathrm{A}$ and $\mathrm{C}$ ). $\mathrm{Pd}$ particle size distributions of the same materials are also reported in Figure 2. A larger number of particles were measured in sample A (135), while only a few (9) were detected in sample $\mathrm{C}$ meaning that no statistical considerations can be made in this case. Sample A particles are found most abundantly at 9 and $13 \mathrm{~nm}$. By contrast, Pd particles were present in larger amounts, were smaller and more uniformly distributed (distribution centred around $5 \mathrm{~nm}$, Figure 2 sample B) when the sample was refluxed in ethanol for $1 \mathrm{hrs}$. TEM and XRD data were in accordance.

The above mentioned analyses show that the presence of $C D$ plays a crucial role in influencing Pd content and PdNP size distribution. The amino alcohol on the Si-G-Und intermediate can coordinate $\mathrm{Pd}$ species, but only on the Si-CD derivative were PdNPs loaded in reasonable amounts. Solvent choice and reaction temperature also influenced NP size distribution on the silica. The smallest NPs were produced under US irradiation.

The Suzuki-Miyaura reaction was tested first as the applicability of the new catalyst was investigated (Table 1). The study initially focused on the optimization of a phenyl boronic acid and halo benzene model reaction. These reactions were performed in a $\mathrm{H}_{2} \mathrm{O}$ /dioxane 9:1 mixture with the aim of following green principles. The study aimed to optimise reaction conditions in terms of lowest catalyst amount and shortest reaction time. As depicted in Table 1 , we compared conventional conditions to MW irradiation as we maximized the catalytic performances of PdNPs/Si-CD.

Complete conversion was obtained with iodobenzene and bromobenzene under conventional conditions with $0.2 \% \mathrm{Pd}$ after $4 \mathrm{~h}$ heating at $100^{\circ} \mathrm{C}$. MW irradiation enabled $\mathrm{Pd}$ amount to be decreased to $0.05 \mathrm{~mol} \%$ while reducing reaction time to $30 \mathrm{~min}$. $8-9 \%$ of starting material was unreacted after $15 \mathrm{~min}$.

Table 1. Suzuki-Miyaura Optimization ${ }^{[a]}$

\begin{tabular}{|c|c|c|c|c|c|c|}
\hline \multicolumn{2}{|c|}{$\mathrm{X}=\mathrm{Br}, \mathrm{I}, \mathrm{Cl}$} & $-\mathrm{B}_{\mathrm{O}}^{\mathrm{OH}}$ & 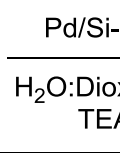 & $\underset{(9: 1)}{\stackrel{D}{\longrightarrow}}$ & 1 & \\
\hline Entry & $x$ & Reaction Co & nditions $^{[a]}$ & $\begin{array}{l}\text { Si-CD-Pd } \\
\text { cat. }\end{array}$ & $\begin{array}{l}\text { Yield } \\
\text { (conv.) }\end{array}$ & $\%$ \\
\hline 1 & 1 & o.b., 100 & ${ }^{\circ} \mathrm{C}, 4 \mathrm{~h}$ & $0.5 \mathrm{~mol} \%$ & 98 (>99) & \\
\hline 2 & 1 & o.b., 100 & ${ }^{\circ} \mathrm{C}, 4 \mathrm{~h}$ & $0.2 \mathrm{~mol} \%$ & 98 (>99) & \\
\hline 3 & 1 & MW, 100 & ${ }^{\circ} \mathrm{C}, 1 \mathrm{~h}$ & $0.5 \mathrm{~mol} \%$ & 99 (>99) & \\
\hline 4 & 1 & MW, 100 & ${ }^{\circ} \mathrm{C}, 1 \mathrm{~h}$ & $0.2 \mathrm{~mol} \%$ & 98 (>99) & \\
\hline 5 & 1 & MW, 100 & ${ }^{\circ} \mathrm{C}, 1 \mathrm{~h}$ & $0.1 \mathrm{~mol} \%$ & 97 (>99) & \\
\hline 6 & I & MW, 100 & ${ }^{\circ} \mathrm{C}, 30^{\prime}$ & $0.2 \mathrm{~mol} \%$ & 96 (>99) & \\
\hline 7 & 1 & MW, 100 & ${ }^{\circ} \mathrm{C}, 15^{\prime}$ & $0.2 \mathrm{~mol} \%$ & $91(92)$ & \\
\hline 8 & 1 & MW, 100 & ${ }^{\circ} \mathrm{C}, 30^{\prime}$ & $0.1 \mathrm{~mol} \%$ & $98(>99)$ & \\
\hline 9 & 1 & MW, 100 & ${ }^{\circ} \mathrm{C}, 30^{\prime}$ & $0.05 \mathrm{~mol} \%$ & $96(>99)$ & \\
\hline 10 & 1 & MW, 100 & ${ }^{\circ} \mathrm{C}, 15^{\prime}$ & $0.1 \mathrm{~mol} \%$ & $90(91)$ & \\
\hline 11 & $\mathrm{Br}$ & o.b., 100 & ${ }^{\circ} \mathrm{C}, 4 \mathrm{~h}$ & $0.5 \mathrm{~mol} \%$ & 98 (>99) & \\
\hline 12 & $\mathrm{Br}$ & o.b., 100 & ${ }^{\circ} \mathrm{C}, 4 \mathrm{~h}$ & $0.2 \mathrm{~mol} \%$ & 98 (>99) & \\
\hline 13 & $\mathrm{Br}$ & MW, 100 & ${ }^{\circ} \mathrm{C}, 1 \mathrm{~h}$ & $0.2 \mathrm{~mol} \%$ & $98(>99)$ & \\
\hline
\end{tabular}




\begin{tabular}{lllll}
14 & $\mathrm{Br}$ & $\mathrm{MW}, 100^{\circ} \mathrm{C}, 1 \mathrm{~h}$ & $0.1 \mathrm{~mol} \%$ & $100(>99)$ \\
15 & $\mathrm{Br}$ & $\mathrm{MW}, 100^{\circ} \mathrm{C}, 30^{\prime}$ & $0.2 \mathrm{~mol} \%$ & $99(>99)$ \\
16 & $\mathrm{Br}$ & $\mathrm{MW}, 100^{\circ} \mathrm{C}, 30^{\prime}$ & $0.1 \mathrm{~mol} \%$ & $99(>99)$ \\
17 & $\mathrm{Br}$ & $\mathrm{MW}, 100^{\circ} \mathrm{C}, 30^{\prime}$ & $0.05 \mathrm{~mol} \%$ & $98(>99)$ \\
\hline
\end{tabular}

[a] all reactions were performed in $\mathrm{H}_{2} \mathrm{O}$ :Dioxane 9:1, 1 eq. aryl-X, 1.1 eq boronic acid, 2 eq. TEA

An array of twelve aryl halides, both electron-rich and electrondeficient, was chosen as Suzuki-Miyaura cross-coupling reaction substrates and phenyl boronic acid was used for further investigations of $\mathrm{Pd} / \mathrm{Si}-\mathrm{CD}$ catalytic performance (Table 2).

Table 2. Scope of Suzuki-Miyaura cross-coupling reactions

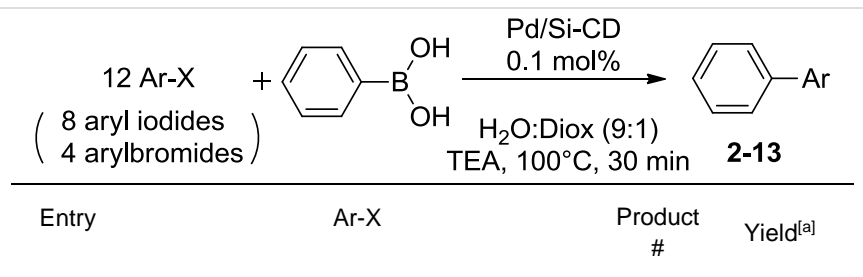

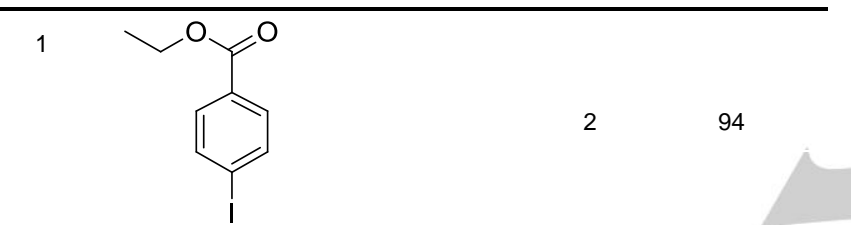

2<smiles>Oc1ccc(I)cc1</smiles>

3<smiles>Ic1ccc(CN2CCOCC2)cc1</smiles>

4<smiles>CC(=O)Nc1ccccc1I</smiles>

5<smiles>Nc1ccccc1I</smiles>

6<smiles>Ic1ccc(Cn2cc(-c3ccccc3)nn2)cc1</smiles>

7

9

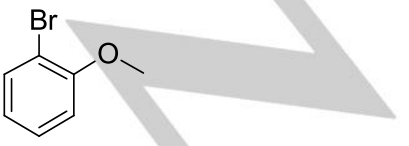<smiles>CC(=O)c1ccc(Br)cc1</smiles>

10<smiles>COc1ccc(Br)cc1</smiles>

11<smiles>CC(=O)c1ccc(Br)s1</smiles>
12

12<smiles>O=[N+]([O-])c1cccc(Br)c1</smiles>

$99^{[c]}$

90

$99^{[b]}$ [a] reaction performed in $\mathrm{H}_{2} \mathrm{O}$ :Dioxane 9:1,1 eq. aryl- $\mathrm{X}, 1.1$ eq. boronic acid, 2 eq. TEA, $0.2 \% \mathrm{~mol} \mathrm{Pd}$, [b] reaction performed with $0.2 \% \mathrm{~mol} \mathrm{Pd}$; [c] reaction performed with $0.5 \% \mathrm{~mol} P d$

The reaction was performed with $0.1 \mathrm{~mol} \% \mathrm{Pd}$ at $100^{\circ} \mathrm{C}$ for 30 min and yields of $61-99 \%$ were achieved. Reaction outcomes showed good aryl iodide and bromide reactivity, while high yields were obtained even in presence of high steric hindrance (Entry 4 , 5, 7, 9 Table 2). The high reaction rate enabled the ethyl 4-iodo benzoate to be selectively converted to the diphenyl derivative in water without hydrolysing the ester moiety (entry 1 , Table 2).

The optimized protocol was used in screening a set of 4 boronic acids with iodo and bromo benzene giving yields of 88 to 99 (Table 3). 2,5-dimethoxy fenil boronic acid surprisingly reacted in $30 \mathrm{~min}$ at $100^{\circ} \mathrm{C}$ to give 97 and $88 \%$ yields with iodo and bromo benzene respectively.

Table 3. Suzuki-Miyaura cross-coupling reaction of iodo and bromo benzene with phenylboronic acid derivatives in aqueous media [a]

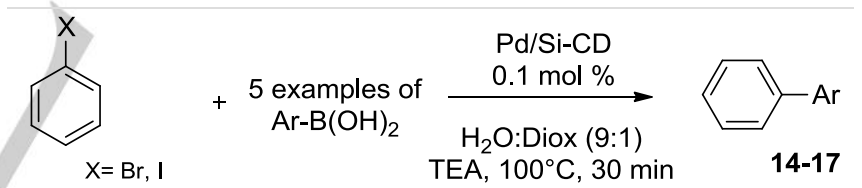

\begin{tabular}{|c|c|c|c|c|}
\hline Entry & Halobenzene & Boronic acid & Product & Yield \\
\hline 1 & Ph-I & & 14 & 99 \\
\hline 2 & $\mathrm{Ph}-\mathrm{Br}$ & & 14 & 98 \\
\hline 3 & $\mathrm{Ph}-\mathrm{I}$ & & 15 & 98 \\
\hline 4 & $\mathrm{Ph}-\mathrm{Br}$ & & 15 & 97 \\
\hline 5 & $\mathrm{Ph}-\mathrm{I}$ & & 16 & 97 \\
\hline 6 & $\mathrm{Ph}-\mathrm{Br}$ & & 16 & 88 \\
\hline 7 & $\mathrm{Ph}-\mathrm{I}$ & & 17 & 99 \\
\hline 8 & $\mathrm{Ph}-\mathrm{Br}$ & & 17 & 98 \\
\hline
\end{tabular}

[a] reaction performed in $\mathrm{H}_{2} \mathrm{O}$ :Dioxane 9:1, 1 eq. iodo or bromo benzene, 1.1 eq. boronic acid, 2 eq. TEA, $0.1 \% \mathrm{~mol} P d$. 
The abovementioned results prompted us to continue with a study of $\mathrm{Pd} / \mathrm{Si}-\mathrm{CD}$ catalytic activity in the Heck reaction. A series of reactions were performed using varying conditions for the sake of optimizing the protocol.

Table 4. Heck Optimization

\begin{tabular}{|c|c|c|c|c|c|}
\hline \multicolumn{3}{|c|}{$\begin{array}{l}\mathrm{R}=\mathrm{H}, \\
\mathrm{OMe}\end{array}$} & \multicolumn{3}{|c|}{$\begin{array}{l}18 \mathrm{R}=\mathrm{H}, \\
19 \mathrm{R}=\mathrm{OMe}\end{array}$} \\
\hline Entry & $\mathrm{R}$ & Solvent & $\begin{array}{l}\text { Reaction } \\
\text { Conditions }^{[a]}\end{array}$ & $\begin{array}{c}\text { Si-CD-Pd } \\
\mathrm{mol} \%\end{array}$ & $\begin{array}{l}\text { Yield \% } \\
\text { (conv) }\end{array}$ \\
\hline 1 & $\mathrm{H}$ & DMF & $\begin{array}{l}\mathrm{Et}_{3} \mathrm{~N} \quad \text { o.b., } \\
110^{\circ} \mathrm{C} \text {, o.n. }\end{array}$ & 1 & $52(60)$ \\
\hline 2 & $\mathrm{H}$ & $\begin{array}{l}\mathrm{H}_{2} \mathrm{O} \text { :Diox } \\
1: 1\end{array}$ & $\begin{array}{l}\mathrm{K}_{2} \mathrm{CO}_{3} \text { o.b., } \\
90^{\circ} \mathrm{C} \text {, o.n. }\end{array}$ & 1 & $\begin{array}{l}98 \\
(>99)\end{array}$ \\
\hline 3 & $\mathrm{H}$ & $\begin{array}{l}\mathrm{H}_{2} \mathrm{O} \text { :Diox } \\
1: 1\end{array}$ & $\begin{array}{l}\mathrm{K}_{2} \mathrm{CO}_{3} \text { o.b., } \\
90^{\circ} \mathrm{C}, 4 \mathrm{~h} .\end{array}$ & 1 & $\begin{array}{l}98 \\
(>99)\end{array}$ \\
\hline 4 & $\mathrm{H}$ & $\begin{array}{l}\mathrm{H}_{2} \mathrm{O} \text { :Diox } \\
1: 1\end{array}$ & $\begin{array}{l}\mathrm{K}_{2} \mathrm{CO}_{3} \text {, o.b., } \\
90^{\circ} \mathrm{C}, 4 \mathrm{~h}\end{array}$ & 0.5 & $\begin{array}{l}98 \\
(>99)\end{array}$ \\
\hline 5 & $\mathrm{H}$ & $\begin{array}{l}\mathrm{H}_{2} \mathrm{O} \text { :Diox } \\
1: 1\end{array}$ & $\begin{array}{l}\mathrm{K}_{2} \mathrm{CO}_{3}, \mathrm{MW}, \\
120^{\circ} \mathrm{C}, 4 \mathrm{~h}\end{array}$ & 1 & $\begin{array}{l}96 \\
(>99)\end{array}$ \\
\hline 6 & $\mathrm{H}$ & DMF & $\begin{array}{l}\mathrm{Et}_{3} \mathrm{~N}, \quad \mathrm{MW} . \\
120^{\circ} \mathrm{C}, 4 \mathrm{~h}\end{array}$ & 1 & $\begin{array}{l}87 \\
(>99)\end{array}$ \\
\hline 7 & $\mathrm{H}$ & DMF & $\begin{array}{l}\mathrm{K}_{2} \mathrm{CO}_{3}, \\
\mathrm{MW} ., \\
120^{\circ} \mathrm{C}, 4 \mathrm{~h}\end{array}$ & 1 & $85(98)$ \\
\hline 8 & $\mathrm{H}$ & $\begin{array}{l}\mathrm{H}_{2} \mathrm{O} \text { :Diox } \\
1: 1\end{array}$ & $\begin{array}{l}\mathrm{Et}_{3} \mathrm{~N}, \quad \mathrm{MW} . \\
120^{\circ} \mathrm{C}, 4 \mathrm{~h}\end{array}$ & 1 & $34(56)$ \\
\hline 9 & $\mathrm{H}$ & $\begin{array}{l}\mathrm{H}_{2} \mathrm{O} \text { :Diox } \\
1: 1\end{array}$ & $\begin{array}{l}\mathrm{K}_{2} \mathrm{CO}_{3}, \mathrm{MW} \\
120^{\circ} \mathrm{C}, 1 \mathrm{~h}\end{array}$ & 1 & $\begin{array}{l}99 \\
(>99)\end{array}$ \\
\hline 10 & $\mathrm{H}$ & $\begin{array}{l}\mathrm{H}_{2} \mathrm{O} \text { :Diox } \\
1: 1\end{array}$ & $\begin{array}{l}\mathrm{K}_{2} \mathrm{CO}_{3}, \mathrm{MW}, \\
120^{\circ} \mathrm{C}, \quad 30 \\
\min \end{array}$ & 1 & $87(90)$ \\
\hline 11 & $\mathrm{H}$ & $\begin{array}{l}\mathrm{H}_{2} \mathrm{O} \text { :Diox } \\
1: 1\end{array}$ & $\begin{array}{l}\mathrm{K}_{2} \mathrm{CO}_{3}, \mathrm{MW} \\
120^{\circ} \mathrm{C}, 1 \mathrm{~h}\end{array}$ & 0.5 & $\begin{array}{l}97 \\
(>99)\end{array}$ \\
\hline 12 & $\mathrm{H}$ & $\begin{array}{l}\mathrm{H}_{2} \mathrm{O} \text { :Diox } \\
1: 1\end{array}$ & $\begin{array}{l}\mathrm{K}_{2} \mathrm{CO}_{3}, \mathrm{MW}, \\
120^{\circ} \mathrm{C}, 1 \mathrm{~h}\end{array}$ & 0.2 & $89(95)$ \\
\hline 13 & OMe & $\begin{array}{l}\mathrm{H}_{2} \mathrm{O}: \text { Diox } \\
1: 1\end{array}$ & $\begin{array}{l}\mathrm{K}_{2} \mathrm{CO}_{3}, \mathrm{MW} \\
120^{\circ} \mathrm{C}, 1 \mathrm{~h}\end{array}$ & $1 \%$ & $66(84)$ \\
\hline 14 & OMe & $\begin{array}{l}\mathrm{H}_{2} \mathrm{O} \text { :Diox } \\
1: 1\end{array}$ & $\begin{array}{l}\mathrm{K}_{2} \mathrm{CO}_{3}, \mathrm{MW} \\
120^{\circ} \mathrm{C}, 1 \mathrm{~h}\end{array}$ & 0.5 & $71(76)$ \\
\hline 15 & OMe & $\begin{array}{l}\mathrm{H}_{2} \mathrm{O} \text { :Diox } \\
1: 1\end{array}$ & $\begin{array}{l}\mathrm{K}_{2} \mathrm{CO}_{3}, \mathrm{MW} \\
120^{\circ} \mathrm{C}, 1 \mathrm{~h}\end{array}$ & 0.2 & $62(68)$ \\
\hline
\end{tabular}

[a] reactions performed with 1.25 eq. styrene, 2 eq. of base

The model substrates for the initial screening were phenyl iodide and styrene leading to stilbene. As summarized in Table 4, Pd/Si$C D$ quantitatively converted the starting material under conventional conditions in $4 \mathrm{~h}$ at reflux in Dioxane: $\mathrm{H}_{2} \mathrm{O}$ 1:1 (Table 4 entry 1-4). The reaction was successful with $\mathrm{K}_{2} \mathrm{CO}_{3}$ as a base and $0.5 \mathrm{~mol} \%$ of $\mathrm{Pd}$. MW irradiation sped up the reaction and full conversion was obtained after $1 \mathrm{~h}$, while catalyst amount was reduced to $0.2 \mathrm{~mol} \%$ (Table 4, Entry 11-12). Excellent results were also achieved in DMF with $\mathrm{K}_{2} \mathrm{CO}_{3}$ as a base (Table 4, Entry 7). A slight decrease in yield was observed when optimized protocols were performed with 4-iodoanisole.

Table 5. Scope of the Heck reaction with different aryl iodines and bromides and styrene ${ }^{[a]}$

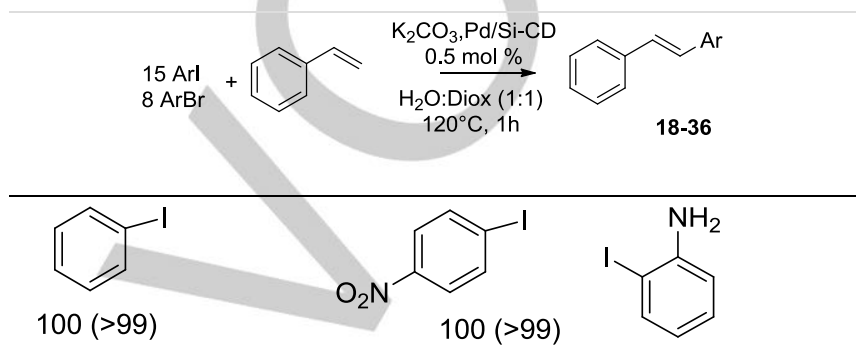

$100(98)$<smiles>O=C(O)Oc1ccc(I)cc1</smiles><smiles>O=[W]O[Na]</smiles><smiles>Nc1ccc(I)cc1</smiles><smiles>CC(=O)c1ccc(I)cc1</smiles><smiles>O=S(=O)(O)Cc1ccc(I)cc1</smiles>
$100(96)^{b}$<smiles>Cc1ccccc1I</smiles>
$100(95)$

100 (97)<smiles>CC(=O)Nc1ccccc1I</smiles>
$100(>99)$<smiles>Oc1cccc(I)c1</smiles>

100 (99)<smiles>COc1ccc(Br)cc1</smiles><smiles>COc1cccc(Br)c1</smiles><smiles>CC(=O)c1ccc(Br)s1</smiles>
33 (>99)<smiles>COc1ccccc1Br</smiles>

$100(97)$<smiles>Ic1ccc(Cn2cc(-c3ccccc3)nn2)cc1</smiles>

34 (100)

$100(96)$ 
<smiles>Cc1cc(C)c(Br)c(C)c1</smiles><smiles>Brc1ccccc1</smiles><smiles></smiles>

100 (97)<smiles>O=[N+]([O-])c1ccc(Br)cc1</smiles><smiles>O=[N+]([O-])c1cccc(Br)c1</smiles>

$100(>99)$

[a] The reactions were performed in $\mathrm{H}_{2} \mathrm{O}$ :Dioxane 1:1, 1.25 eq. styrene, 2 eq. $\mathrm{K}_{2} \mathrm{CO}_{3}, 0.5 \% \mathrm{~mol} \mathrm{Pd}, 120^{\circ} \mathrm{C}, 1 \mathrm{~h}$ [b] the reaction was in DMF

Table 6. Scope of the Heck reaction with different aryl iodines and bromides and butylacrylate. ${ }^{[a]}$

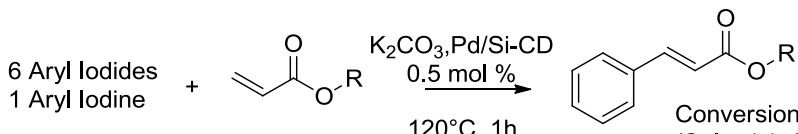

$$
\begin{aligned}
& \mathrm{R}=\mathrm{nBu}, \quad 120^{\circ} \mathrm{C}, 1 \mathrm{~h} \quad \mathrm{R}=\mathrm{nBu}, \quad \text { (Selectivity) } \\
& \text { tBu } \quad 37-46
\end{aligned}
$$

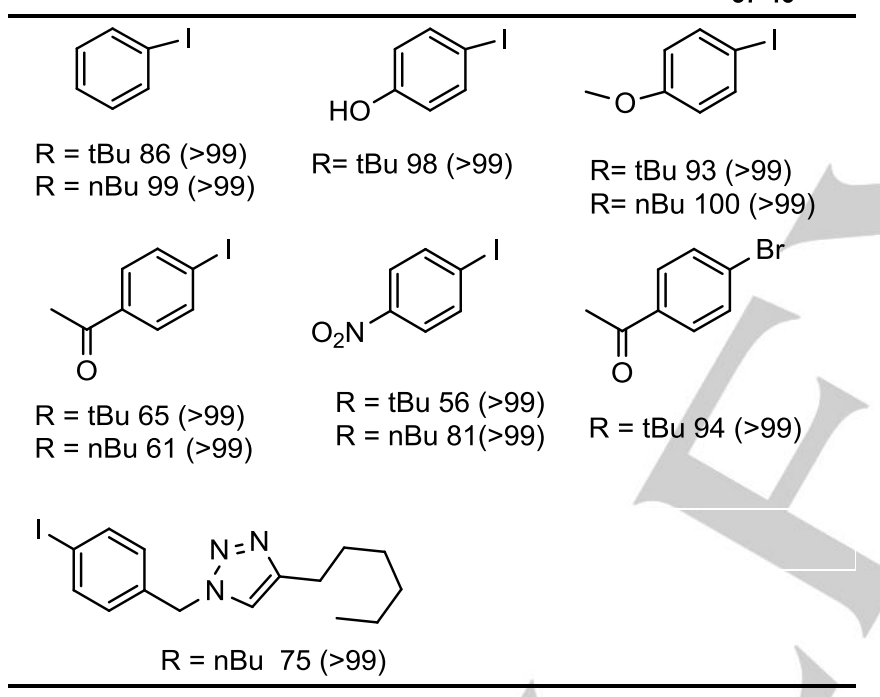

[a] reactions performed with 1.25 eq. acrylate, 2 eq. $\mathrm{K}_{2} \mathrm{CO}_{3}, 0.5 \% \mathrm{~mol} \mathrm{Pd}$, $120{ }^{\circ} \mathrm{C}, 1 \mathrm{~h}$. the solvent was $\mathrm{H}_{2} \mathrm{O}$ :Dioxane $1: 1$ for the reaction with $t$-buty acrylate; while DMF was chosen for $n$-butyl acrylate.

In order to gauge the versatility of this protocol, a large number of substrates were screened in parallel using the MW reactor (SynthWave by Milestone) which is well suited to parallel syntheses at any reaction temperature and gas pressure (up to $300^{\circ} \mathrm{C}$ and 200 bar). Aryl bromides and iodides with electronwithdrawing and electron-donating substituents were reacted with styrene, $n$-Butyl and terz-Butyl acrylate. Excellent results were obtained in $1 \mathrm{~h}$ with $0.5 \mathrm{~mol} \% \mathrm{Pd}$ without the addition of ligands and the reactions almost always gave quantitative yields (see Table 5 and 6). Triazolyl and thiazole iodo derivatives were included in the list of reagents, as representative of heterocyclic compounds, and yielded the desired product in the 34 to $75 \%$ yield range.

The regiochemical outcome of the Heck reaction with unsymmetrical olefins is of utmost importance and so Tables 5 and

6 not only indicate conversion, but also selectivity. While acrylates showed $>99 \%$ selectivity, the styrene gave a slight decrease. Regiochemistry was influenced by steric and electronic factors: sterically hindered and electron rich halides showed selectivities in the $98-95 \%$ range, while all the other experiments only furnished the desired regioisomer. As depicted in Figure 3, the $\alpha$ substituted regioisomer was the main side product when a mixture of isomers was observed. $\alpha$-substitution products were present in the $1-3 \%$ range, while the $\beta$-cis regioisomer was detected at $0.5 \%$ when the reaction was performed with halo anisoles, iodophenol, 2-methyl iodobenzene, 2,5 dimethyl halobenzenes and 2-amino iodobenzene.

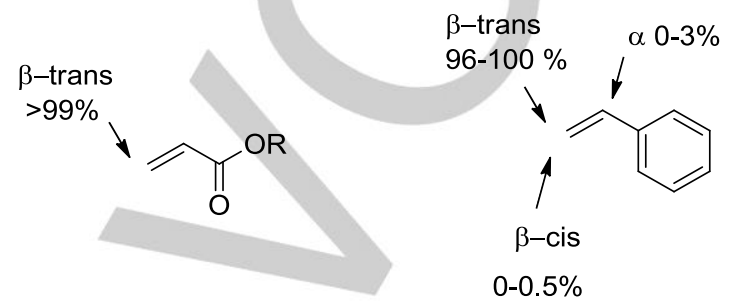

Figure 3. Ligand-free Heck reaction: observed range of selectivity.

An example of the intramolecular ligand free Heck reaction ${ }^{25}$ was also successfully performed to display the high reactivity of this catalyst. The carbazole derivative was obtained in $85 \%$ after $1 \mathrm{~h}$ at $100^{\circ} \mathrm{C}$ with $0.5 \mathrm{~mol} \% \mathrm{Pd}$. (see Scheme 2)<smiles>O=C1C=C(Nc2ccccc2I)CCC1</smiles>

Scheme 2. Intramolecular Heck reaction

$\mathrm{Pd} / \mathrm{Si}-\mathrm{CD}$ reusability was also checked (see Fig. 4). The crosscoupling reaction was carried out with phenyl iodide and phenyl boronic acid in the presence of $0.1 \mathrm{~mol} \%$ catalyst to better understand catalyst performance. The nano-catalyst was separated by filtration, washed with water, DCM, dioxane and reused. As depicted in figure 2 , no significant loss in catalytic activity was observed after five cycles.

To better understand if the lost of activity was due to PD leaching an ICP analysis of the catalyst after first usage was carried out and it was observed that catalyst loading remained constant. 14d. Measured Pd weight \% was $6.0 \%$ before usage and 5.95 after (Table 1,Entry 3). An XRD analysis which was carried out on a sample after catalysis only showed a slight increase in particle size, from 6.2 to $7.1 \mathrm{~nm}$ after usage (Figure 1, curve d).

To confirm that the reaction was catalyzed by $\mathrm{Pd} / \mathrm{Si}-\mathrm{CD}$ and not by the leached homogeneous Pd species, the model Suzuki reaction as well as the Heck reaction with iodo benzene and phenylboronic or styrene respectively were performed in two steps (see Supporting Information). The reaction was performed in oil bath and the hot reaction mixtures were filtered to remove 
the $\mathrm{Pd} / \mathrm{SiCD}$. The reaction was monitored by GC-MS and only a slightly increased conversion was observed (1-5\%), suggesting that all catalytic species were solid supported. ${ }^{26}$

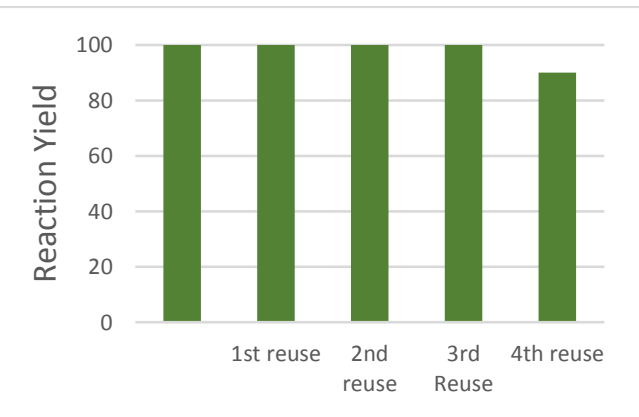

Figure 4. PdNPs/Si-CD catalyst reusability. Reaction conditions 1 eq. bromo benzene, 1.1 eq. boronic acid, 2 eq. TEA, $0.1 \% \mathrm{~mol} \mathrm{Pd}(\mathrm{Pd} / \mathrm{Si}-\mathrm{CD})$, $\mathrm{H}_{2} \mathrm{O}$ :Dioxane 9:1, $100^{\circ} \mathrm{C}, 30^{\prime}$

Finally, we explored the hydrogenation of a range of unsaturated hydrocarbons under $1 \mathrm{~atm}$ initial hydrogen pressure at r.t.. $\mathrm{Pd} / \mathrm{Si}$ $\mathrm{CD}(0.15 \mathrm{Pd} \mathrm{mol} \%)$ showed excellent catalytic activity in the reduction of substrates with double and triple bonds to the corresponding alkane with excellent yields (>99\%). The reduction of the azido and nitro groups furnished the corresponding amines in $2 \mathrm{~h}$. Benzaldehyde gave the corresponding alcohol in $1 \mathrm{~h}$ at $50^{\circ} \mathrm{C}$ in a $>99 \%$ yield and the $p$-nitrobenzaldehyde was selectively reduced to $p$-amino benzaldehyde o.n. at r.t.

Table 7. Hydrogenation reaction ${ }^{[a]}$

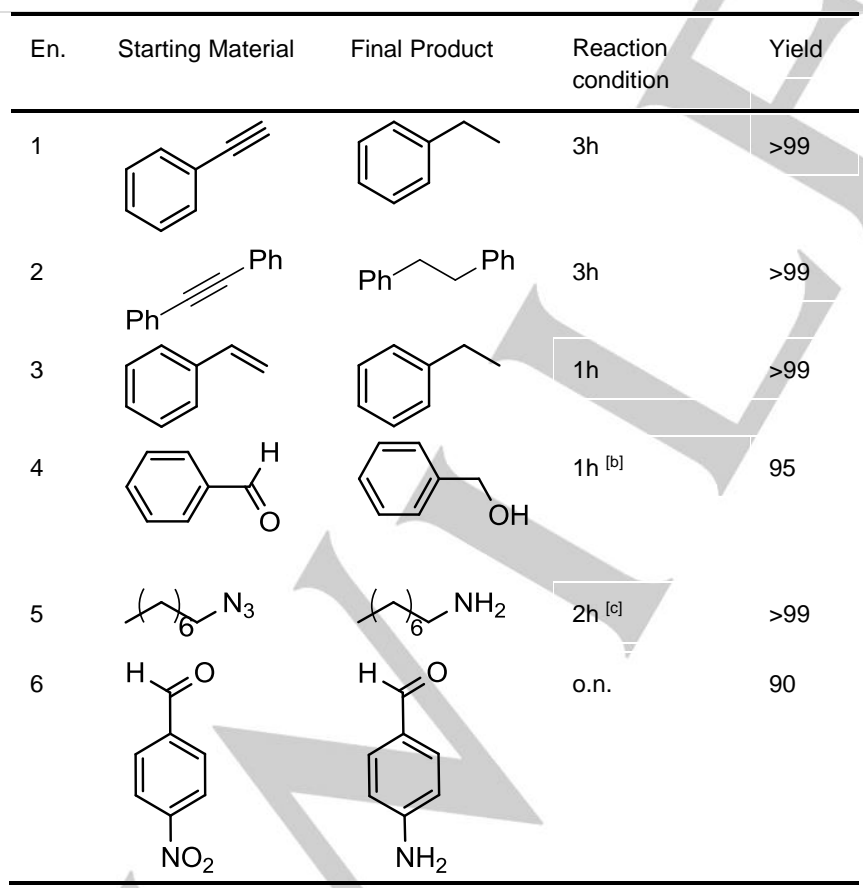

[a] reactions performed in hexane, $0.15 \% \mathrm{~mol} \mathrm{Pd}$, r.t., [b] The reaction was performed at $50^{\circ} \mathrm{C},[\mathrm{c}]$ the reaction was performed in methanol.
Conscious of the importance of alkyne semihydrogenation in providing the alkene derivative and of conventional monometallic $\mathrm{Pd}$ catalysts not giving high selectivity in these processes, ${ }^{27}$ we proceed to evaluate the kinetics of the catalytic hydrogenation of phenyl acetylene. Five experiments were performed at room temperature under $1 \mathrm{~atm}$ initial hydrogen pressure and reactions underwent workup and analysis after 15, 30, 45, 60, 90, 120, 150 min. As depicted in Figure 5, full conversion of the alkyne was obtained in $60 \mathrm{~min}$ and the highest selectivity (alkene/alkane) achieved was $>95 \%$.

Figure 5. Percentage profile of the hydrogenation of phenyl acetylene with $\mathrm{Pd} / \mathrm{Si}-\mathrm{CD} \mathbf{\bullet} \boldsymbol{\Lambda} \bullet$

\section{Conclusions}

In conclusion, we report the preparation of a new hybrid CD silica derivative supported PdNP catalyst. As the presence of a coordinating group is considered the key factor in the formation of small sized, homogeneously dispersed Pd nanoparticles, we herein demonstrate that $C D$ grafted silica is an optimal support for this task. The amino alcohol groups and tryazole on the spacer can also coordinate Pd species and influence PdNP content, size and distribution on the silica surface. An extensive study of the catalytic performances of this catalyst in ligand free C-C Suzuki and Heck couplings over a large number of aryl iodides and bromides has been reported. The catalyst exhibited excellent results and MW irradiation cut down reaction times. Pd/Si-CD showed high activity and selectivity in the hydrogenation reaction, while the semihydrogenation of phenylacetylene was studied giving excellent alkene/alkane selectivity. All protocols were designed to be ligand free and carried out without the addition of a stabilizer, in accordance with green chemistry criteria, while catalyst reuse was also evaluated. The Suzuki-Miyaura reaction was repeated five times and no significant loss in catalytic activity was observed. An ICP analysis of the catalyst after usage confirmed that catalyst amount was constant and XRD showed that NP diameter only increased slightly after usage. 


\section{Experimental Section}

Materials and Method

All commercially available reagents and solvents were used without further purification. SIPERNAT 320 amorphous silica was supplied by Evonik Degussa. Reactions were carried out in professional MW reactor SynthWave (MLS GmbH, Milestone S.r.l. Mechanochemistry was performed in a planetary ball mill PM100 (Retsch GmbH). Si-G-U-CD was fully characterized as described in one of our previous studies. The cations were determined with a Perkin Elmer Optima 7000 (Perkin Elmer, Norwalk, Connecticut, USA) inductively coupled plasma-optical emission spectrometer (ICP-OES).

Preparation of Si-CD

(3-Glycidoxypropyl)methyldiethoxysilane $(0.934 \mathrm{~mL}, 0.420 \mathrm{~mol})$ was dissolved in toluene $(10 \mathrm{~mL})$ and silica SIPERNAT $320(1 \mathrm{~g})$ was added. The suspension was either heated under stirring in an oil bath $\left(80^{\circ} \mathrm{C}\right.$ for 5 h) or in a MW reactor $\left(80^{\circ} \mathrm{C}\right.$ for $1 \mathrm{~h}$, average power $53 \mathrm{~W}$ ). The modified silica was then filtered, washed thoroughly and dried under vacuum. SiGPMS (1 g) and 10- undecynil-1-amine (0.275 g, $1.64 \mathrm{mmol})$ were dissolved in DMF $(3 \mathrm{~mL})$. The solution was either heated to $80^{\circ} \mathrm{C}$ and stirred for $24 \mathrm{~h}$ or the reaction was performed in a $\mathrm{MW}$ reactor $\left(100^{\circ} \mathrm{C}\right.$ for $2 \mathrm{~h}$, average power approximately $20 \mathrm{~W}$ ). The silica was finally filtered and washed with DMF, water and toluene and dried under vacuum. Si-G-Und $(1 \mathrm{~g})$, 6-monoazido- $\beta$-CD (1.95 g, $1.68 \mathrm{mmol}), \mathrm{CuSO}_{4} * 4 \mathrm{H}_{2} \mathrm{O}(0.100 \mathrm{~g}, 0.4$ $\mathrm{mmol})$, and ascorbic acid $(0.148 \mathrm{~g}, 0.84 \mathrm{mmol})$ were dissolved in $\mathrm{H}_{2} \mathrm{O}$ (30 $\mathrm{mL}$ ). The reaction was heated under $\mathrm{MW}$ at $80^{\circ} \mathrm{C}$ for $2 \mathrm{~h}$ (average power approximately $12 \mathrm{~W}$ ). Silica was filtered, washed with water and dried under high vacuum. The silica was purified of copper salts via the addition

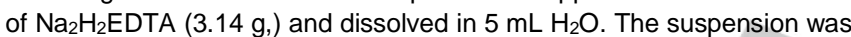
left under magnetic stirring o.n.. The silica was then filtered, washed with water and dried under high vacuum.

Preparation of the $\mathrm{Pd} / \mathrm{Si}-\mathrm{CD}$ catalyst

$\mathrm{Pd}(\mathrm{OAc})_{2}(0.0024 \mathrm{~g}, 1.09 \mathrm{mmol})$ was dissolved in ethanol $(5 \mathrm{~mL})$ and $\mathrm{Si}-$ CD ( $0.250 \mathrm{~g}$ ) was added. The suspension was heated under reflux and stirred in an oil bath for $2 \mathrm{~h}$.

When the preparation of the catalyst was performed under US irradiation the reaction was sonicated (cup-horn, $90-100 \mathrm{~W}, 20.4 \mathrm{kHz}$ ), for $1 \mathrm{~h}$ and the temperature was maintained at $35-37^{\circ} \mathrm{C}$.

\section{Characterization}

Powder X-Ray Diffraction (XRD) patterns were measured on a PW3050/60 X'Pert PRO MPD diffractometer (Panalytical) working in Bragg-Brentano geometry using Cu K $\alpha$ radiation $(\mathrm{k}=1.5406 \AA$ ) and operated at $45 \mathrm{kV}, 40$ $\mathrm{mA}$ with and step size of $0.0170^{\circ}$ and time per step of 90 secs. Crystallite size $D=4 / 3 L$ was calculated by applying the Scherrer's equation to the (111) peak at $39.33^{\circ}$ :

$$
\mathrm{L}=\mathrm{k} \lambda /(\beta \cos \theta)
$$

where $k$ is the $X$-ray wavelength, $\beta$ the measured broadening of the diffraction peak and $\theta$ the diffraction angle. The measured $\beta$ value was corrected by subtracting instrumental line broadening, estimated at $0.02^{\circ}$.

Transmission Electron Microscopy (HRTEM) measurements were performed on a JEM 3010-UHR microscope (JEOL Ltd.) operating at 300
$\mathrm{kV}$. The sample powder was dispersed on a copper grid coated with a perforated carbon film for measurements.

\section{Suzuki-Miyaura reaction}

Aryl halide $(0.5 \mathrm{mmol}$.), boronic acid $(0.55 \mathrm{mmol}$.) and TEA (1 $\mathrm{mmol})$ were dissolved in $5 \mathrm{~mL}$ of $\mathrm{H}_{2} \mathrm{O}$ :Dioxane $(9: 1)$ and $\mathrm{Pd} / \mathrm{Si}-\mathrm{CD}(0.2 \mathrm{~mol} \%$ $0.5 \mathrm{~mol} \%$ ) were added. The reaction was carried out under magnetic stirring in a MW reactor SynthWave at $100^{\circ} \mathrm{C}$ for 1 hour. The crude product was filtered on a Büchner funnel with a sintered glass disc using $\mathrm{CH}_{2} \mathrm{Cl}_{2}$ and Dioxane to wash the catalyst. After concentration to half volume under vacuum, the mixture was extracted with a $\mathrm{HCl}$ solution and $\mathrm{CH}_{2} \mathrm{Cl}_{2}$, washed with $\mathrm{H}_{2} \mathrm{O}$ three times and finally dried $\left(\mathrm{Na}_{2} \mathrm{SO}_{4}\right)$. The crude product was analyzed by GC-MS and purified by flash chromatography on silica gel to afford the desired product. The pure product was analyzed using ${ }^{1} \mathrm{H}$ and ${ }^{13} \mathrm{C}$ NMR spectroscopy and MALDI-TOF mass spectrometry after dissolution in an appropriate solvent.

\section{Heck reaction}

The aryl halide $(0.16 \mathrm{mmol})$, alkene or acrylate $(0.2 \mathrm{mmol}), \mathrm{K}_{2} \mathrm{CO}_{3}(1 \mathrm{mmol})$ and Si-CD-PdNPs catalyst ( $1 \mathrm{~mol} \%$ ) were dissolved in a solution of $\mathrm{H}_{2} \mathrm{O}$ : 1,4-Dioxane (1:1) or DMF (2 $\mathrm{mL})$. The reaction was heated under MW at $120{ }^{\circ} \mathrm{C}$ for $30 \mathrm{~min}$ (average power approximately $25 \mathrm{~W}$ ). The crude was filtered and washed with DCM. The desired product was extracted with DCM. The organic layer was washed three times with acid $\mathrm{H}_{2} \mathrm{O}$ and finally dried $\left(\mathrm{Na}_{2} \mathrm{SO}_{4}\right)$ and under high vacuum.

\section{Hydrogenation reaction}

The substrate (1 eq.) was dissolved in $3 \mathrm{~mL}$ of hexane (or $\mathrm{MeOH}$ ) and $\mathrm{Pd} / \mathrm{Si}-\mathrm{CD}(0.156 \mathrm{~mol} \%)$ were added to the mixture. The reaction was carried out under magnetic stirring in an oil bath at r.t. or $50{ }^{\circ} \mathrm{C}$ for 1 to 2 hours. The solution was filtered through a $0.45 \mu \mathrm{m}$ syringe filter and dried. The desired product was obtained without further purification.

\section{Acknowledgements}

This investigation was funded by the University of Turin (fondi ricerca locale 2013) and the EU project MAPSYN: under grant agreement No. CP-IP 309376 of the $7^{\text {th }}$ Framework Program. This work was partly carried out by Marco Bonito during his master thesis in Industrial Pharmacy. We thank Dr. Agnese Glacomino, Department of Drug Science and Technology, University of Torino, for performing the ICP analysis.

Keywords: Organic-inorganic hybrid materials $\cdot$ Heterogeneous catalysis $•$ Cyclodextrin $\cdot$ Palladium Nanoparticles $•$ C-C coupling

[1] M. Haruta, N. Yamada, T. Kobayashi, S. lijima, J. Catal. 1989, 115, 301 $-309$

[2] A.T. Bell, Science 2003, 299, 1688-1691.

[3] R.G. Freeman, K.C. Grabar, K.J. Allison, R.M. Bright, J.A. Davis, A.P. Guthrie, M.B. Hommer, M.A. Jackson, P.C. Smith, Science 1995, 267 1629-1631

[4] a) C. Burda, X. Chen, R. Narayanan, M. A. El-Sayed, Chem. Rev. 2005 105, 1025 - 1102; b) M. A. Mahmoud, C. E. Tabor, Y. Ding, Z. L. Wang, M. A. El-Sayed, J. Am. Chem. Soc. 2008, 130, 4590 - 4591; c) P. Jaya, P. Tarasankar Nanoscale 2015, 7, 14159-14190; d) B. Roldan Cuenya, 
F. Behafarid, Surf. Sci. Rep. 2015, 70, 135-187; e) K. M. Bratlie, H. Lee, K. Komvopoulos, P. Yang, G. A. Somorjai, Nano Lett. 2007, 7, 3097 3101.

[5] a) C.J. Zhong, J.R. Regalbuto in Comprehensive Inorganic Chemistry, Vol 2 (Eds: J. Reedijk, K. Poeppelmeier) Elsevier, Amsterdam, Netherlands 2013, 7, pp. 75-102; b) Xu, L. Chen, X. Wang, W. Yao, Q. Zhang, Nanoscale 2015, 7, 10559-10583; c) T. Naoki in Dekker Encyclopedia of Nanoscience and Nanotechnology (Ed: S. E. Lyshevski) CRC Press, Boca Raton, Florida 2014, 4, pp. 2378-2388.

[6] a) H.-Y. Park, I. Jang, N. Jung, Y.-H. Chung, J. Ryu, I.Y. Cha, H.J. Kim, J.H. Jang, S.J. Yoo, Sci. Rep. 2015, 5, 14245/1-14245/7, b) R. Ciriminna, L.M. Ilharco, V. Pandarus, A. Fidalgo, F. Beland, M.; Pagliaro, Nanoscale 2014, 6, 6293-6300, c) S. Iravani, Green Chem. 2011, 13, 2638-2650; d) H. Zhu, M. L. Du, M. Zou, C. Xu, Y. Q. Fu, Dalton Trans. 2012, 41, 1046510471; e) S. B. Kalidindi, B. R. Jagirdar, ChemSusChem., 2012, 5, 6575; f) R. S Varma Curr. Opin. Chem. Eng. 2012, 1, 123-128.

[7] P. G. Gildner, T. J. Colacot, Organometallics 2015, 34, 5497-5508.

[8] T. Xi, Y. Mei, Z. Lu, Org. Lett. 2015, 17, 5939-5941.

[9] S. E. Shockley, J. C. Holder, B. M. Stoltz, Org. Process Res. Dev. 2015, 19, 974-981.

[10] C.C.C.J Seechurn, M.O. Kitching, T.J. Colacot, V. Sniekus, Angew. Chem., Int. Ed. 2012, 51, 5062-5085.

[11] a) I.P. Beletskaya, A.V. Cheprakov, Chem. Rev. 2000, 100, 3009-3066; b) P. Prediger, Y. Genisson, C.R.D. Correia, Curr. Org. Chem. 2013, 17, 238-256; c) N. Liu, C. Liu, X. Rao, Z. Jin, Adv. Chem. Res. 2012, 16, 125146.

[12] H. Bonnemann, W. Brijoux, R. Brinkmann, E. Dinjus, T. Joussen, B. Korall, Angew. Chem., Int. Ed. Engl. 1991, 30, 1312-1314

[13] M. Reetz, J.G. de Vries, Chem. Commun. 2004, 1559-1563.

[14] a) D. Astru, F. Lu, J.R. Aranzaes, Angew. Chem. Int. Ed. 2005, 44, 78527872; b) M.T. Reetz, G. Lohmer, G. Chem. Commun. 1996, 1921-1922 c) S. F. Adil; M. E. Assal; M. Khan,A. Al-Warthan, M.R.H. Siddiqui, L.M. Liz-Marzan, Dalton Trans. 2015, 44, 9709-9717; d) L. Yu, Y. Huang, Z. Wei, Y. Ding, C.; Su, Q. Xu, J. Org. Chem. 2015, 80, 8677-8683.

[15] a) C. E. Tucker, J.G. de Vries, Top Catal. 2002, 19, 111-118; b) X. Xie, G. Gao, Z. Pan, T. Wang, X. Meng, L. Cai Sci. Rep. 2015, 5, 8515; c) X. Wang, G. Meng, C. Zhu, Z. Huang, Y. Qian, K. Sun, X. Zhu, Adv. Funct. Mater. 2013, 23, 5771-5777.
[16] J. G. de Vrie, Dalton Trans., 2006, 421-429.

[17] L. Nikoshvili, E. Shimanskaya, A. Bykova, I. Yuranov, L. Kiwi-Minsker, E. Sulman, Catalysis Today $2015,241,179-188$

[18] R. K. Sharma, S. Sharma, S. Dutta, R. Zborilb, M. B. Gawande, Green Chem. 2015, 17, 3207-3230.

[19] a) R.K. Sharma, S. Sharma, S. Dutta, R. Zboril, M.B. Gawande, Green Chem. 2015, 17, 3207-3230; b) Q. Gao, N. Liu, S. Wang, Y. Tang Nanoscale 2014, 6, 14106-14120; c) H. Song, Acc. Chem. Res. 2015, 48, 491-499; d) X. Du, S.Z. Qiao, Small 2015, 11, 392-413; d) M. Rimoldi, A. Mezzetti, Catal. Sci. Technol. 2014, 4, 2724-2740.

[20] K. Martina, F. Baricco, G. Berlier, M. Caporaso, G. Cravotto ACS Sustainable Chem. Eng., 2014, 2 , 2595-2603.

[21] A. Khalafi-Nezhad, F. Panahi ACS Sustainable Chem. Eng. 2014, 2, 1177-1186.

[22] E. Calcio Gaudino, D. Carnaroglio; K. Martina, G. Palmisano, A. Penoni, G. Cravotto, Org. Proc. Res. Dev. 2015, 19, 499-505; b) E. Calcio Gaudino, S. Tagliapietra, K. Martina, A. Barge, M. Lolli, E. Terreno, D. Lembo, G. Cravotto, Org. Biomol. Chem. 2014, 12, 4708-4715; c) A. Barge, M. Caporaso, G. Cravotto, K. Martina, Katia; P. Tosco, S. Aime, C. Carrera, E. Gianolio, G. Pariani, D. Corpillo, Chem. Eur. J. 2013, 19, 12086-12092.

[23] a) G. Cravotto, E. Calcio Gaudino, P. Cintas, Chem. Soc. Rev. 2013, 42, 7521-7534; b) M. B. Gawande, V. D. B. Bonifácio, R. Luque, P. S. Branco, R. S. Varma Chem. Soc. Rev., 2013, 42, 5522; c) V. Polshettiwar, R.S. Varma, Acc. Chem. Res. 2008, 41, 629-639; d) L. Boffa, S. Tagliapietra G. Cravotto in Microwaves in Nanoparticle Synthesis (Eds: S. Horikoshi, N. Serpone) Wiley, Hoboken, New Jersey, 2013, pp. 55-74.

[24] a) W. Chen, B. Gutmann, C. O. Kappe ChemistryOpen 2012, 1, 39-48; b) V. Sáez, T. J. Mason Molecules 2009, 14, 4284-4299.

[25] . U. S. Sørensen, E. Pombo-Villar, Helv. Chim. Acta. 2004, 87, 82-89.

[26] D.T. D. Tang, K. D. Collins, J. B. Ernst, F. Glorius, Angew. Chem. Int. Ed. 2014, 53, $1809-1813$

[27] Z. Wu, N. Cherkasov, G. Cravotto, E. Borretto, A. O. Ibhadon, J. Medlock, W. Bonrath ChemCatChem 2015, 7, 952 - 959. 
Entry for the Table of Contents (Please choose one layout)

Layout 1:

\section{FULL PAPER}

Text for Table of Contents

Layout 2:

\section{FULL PAPER}

((Insert TOC Graphic here; max. width: $11.5 \mathrm{~cm}$; max. height: $2.5 \mathrm{~cm})$ )
Katia Martina, Francesca Baricco, Marina Caporaso, Gloria Berlier, Giancarlo Cravotto*

Page No. - Page No.

Cyclodextrin-grafted silica supported Pd nanoparticles: an efficient and versatile catalyst for ligand free $\mathrm{C}-\mathrm{C}$ coupling and hydrogenation
Author(s), Corresponding Author(s)*

Page No. - Page No.

Title

Text for Table of Contents 